\title{
Nitrogen Fertilization of a High Yielding White-Kernel Corn in Oxisols and Ultisols in Puerto Rico ${ }^{1,2}$
}

\author{
H. Talleyrand, R. H. Fox, and M. A. Lugo-López ${ }^{3}$
}

\begin{abstract}
Fiela experiments with a high-yielding white-kernel hybrid corn. Funk's G-795W, were conducted on four typical soils of Puerto Rico: two Oxisols (Bayamón sandy loam at Manatí and Catalina clay at Barranquitas) and two Ultisols (Humatas clay at Corozal and Torres clay at Cidra). The main objectives of this study were to determine the yield potential and the optimum level of $\mathrm{N}$ fertilizer for this hybrid in these soils. Auxiliary objectives were to determine the $\mathrm{N}$ supplying power of these soils and the apparent recovery of fertilizer $\mathrm{N}$ by the crop.

High corn yields ( 8.4 tons/ha) were obtained on the Humatas clay with 60 to $120 \mathrm{~kg} / \mathrm{ha}$ of $\mathrm{N}$ fertilizer. Only 5.4 tons/ha of corn were obtained on Bayamón sandy loam at the same rate of fertilization. Apparent $N$ recoveries were 60 to $72 \%$ at these rates. Grain/stover ratios averaged 1.20 on Humatas and only 0.72 on Bayamón. The low grain/stover ratio and the lower grain yields at this site probably could be attributed to late planting and the damage done to the plants by Helminthosporium maydis.

There were no yield or $\mathrm{N}$ uptake responses to applied $\mathrm{N}$ fertilizer on the nonirrigated Catalina and Torres soils. A severe drought reduced stover yields to less than half of those of the irrigated treatments. Maximum nonirrigated grain yields on these soils ( 4.8 tons/ha) were well below the 8.3 tons/ha obtained on Humatas. The N supplying power of these soils was enough to provide 70 to $90 \mathrm{~kg} / \mathrm{ha}$ of plant $\mathrm{N}$.
\end{abstract}

\section{INTRODUCTION}

The deep, extremely weathered, acid and relatively infertile soils classified as Ultisols and Oxisols are considered to be the most extensive

${ }^{1}$ Manuscript submitted to Editorial Board May 22, 1975.

'Joint contribution from the Department of Agronomy, Cornell University, Ithaca, N.Y., and the Agricultural Experiment Station, University of Puerto Rico, Mayagüez Campus, Río Piedras, P.R. This study was part of the investigations supported by the USAID under research contract ta-c-1104 entitled: "Soil Fertility in the Humid Tropics."

${ }^{3}$ Research Technician, Assistant Professor of Soil Science, Cornell University, and Professor and Soil Scientist, Agricultural Experiment Station, University of Puerto Rico, Mayagüez Campus, Río Piedras, P.R. 
soil orders of the Humid Tropics. In Puerto Rico they account for almost $30 \%$ of the total land area. During the past 5 years research to determine the fertilization and management requirements of these soils has been intensified in an effort to determine their potential productivity.

Fox et al. ${ }^{4}$ have reported the results of $15 \mathrm{~N}$ fertilization field experiments conducted in Oxisols and Ultisols of Puerto Rico from 1970 to 1972 using Pioneer X-306, a hybrid corn developed in Jamaica for tropical conditions. Their results showed that postplant $\mathrm{N}$ applications are much more efficient than preplant applications in increasing corn yields and fertilizer $\mathrm{N}$ recovery. They concluded that the bulk of $\mathrm{N}$ should be applied just before the period of maximum growth, i.e., approximately 5 weeks after germination. Their results demonstrated that the clayey Oxisols and Ultisols of Puerto Rico have a relatively high N supplying power. When there were no limiting climatic or disease factors and there was a response to $\mathrm{N}$, the recovery of postplant $\mathrm{N}$ was comparable to that in temperate areas. Near maximum corn grain yields were obtained with $67 \mathrm{~kg} / \mathrm{ha}$ of postplant N. Furthermore, soil inorganic $\mathrm{N}$ content was not generally a good index of soil $\mathrm{N}$ supplying power in these soils. They found very little residual effect of applied fertilizer N.

The objectives of the work herein reported were to determine the yield potential and the optimum level of $\mathrm{N}$ fertilizer for the white-kernel hybrid corn Funk's G-795W in several Oxisols and Ultisols representative of humid tropical soils. Auxiliary objectives were to determine the apparent recovery of fertilizer $\mathrm{N}$ by the crops and the $\mathrm{N}$ supplying power of these soils and to observe the performance under tropical conditions of this hybrid that is widely grown in the Southeastern United States.

\section{MATERIALS AND METHODS}

Field experiments were conducted at Manati on a Bayamón sandy loam (Oxisol); at Corozal, on a Humatas clay (Ultisol); at Barranquitas, on a Catalina clay (Oxisol); and at Cidra, on a Torres clay (Ultisol). The Manatî site is located on the northern coastal plain of Puerto Rico and the other three sites are in the interior uplands. The average summer maximum and minimum temperatures are approximately $29^{\circ}$ and $21^{\circ} \mathrm{C}$ at the interior sites and $32^{\circ}$ and $22^{\circ} \mathrm{C}$ at the coastal site. The average winter maximum and minimum temperatures are approximately $3^{\circ} \mathrm{C}$ lower than in the summer at all sites. Solar radiation ranges from an average of 300 langleys/day in the winter to 500 langleys/day in the summer. Average yearly precipitation for all sites is between 1,650 and $2,000 \mathrm{~mm} /$ year. The evaporation from a class A pan in the summer is

${ }^{4}$ Fox, R. H., Talleyrand, H., and Bouldin, D. R., Nitrogen fertilization of corn and sorghum grown in Oxisols and Ultisols in Puerto Rico, Agron. J., 66: 534-40, 1974. 
approximately $6 \mathrm{~mm} /$ day in the coastal plain site and $5 \mathrm{~mm} /$ day in the interior sites. This drops to 4 and $3 \mathrm{~mm} /$ day for the coastal and interior sites, respectively, during the winter.

All the experiments followed a randomized block design with seven treatments and five replications. The plots were $4.5 \times 9 \mathrm{~m}$.

Seven $\mathrm{N}$ rates were included using urea as the source. Rates ranged from 0 to $200 \mathrm{~kg} / \mathrm{ha}$ on Humatas and Bayamón soils, from 0 to $160 \mathrm{~kg} / \mathrm{ha}$ on Catalina, and from 0 to $100 \mathrm{~kg} / \mathrm{ha}$ on Torres.

The two sites with irrigation facilities were planted in late March and early April 1974 and harvested in July. Planting at the other two sites was delayed until the beginning of the spring-summer rains in late May and harvested in late September. All sites were machine planted at a seeding rate of $56,000 \mathrm{seed} / \mathrm{ha}$ with $76 \mathrm{~cm}$ between rows.

On Bayamón soil one-fourth of the $\mathrm{N}$ was broadcast prior to planting and incorporated into the soil, and three-fourths was banded as a postplant application. On all other soils all the $\mathrm{N}$ was applied in bands a month after planting.

All plots received a blanket application of $100 \mathrm{~kg} / \mathrm{ha}$ of $\mathrm{P}$ as triple superphosphate, $100 \mathrm{~kg} / \mathrm{ha}$ of $\mathrm{K}$ as sulfate, $75 \mathrm{~kg} / \mathrm{ha}$ of $\mathrm{Mg}$ as sulfate, and enough lime to bring the soil $\mathrm{pH}$ to 5.5. The blanket fertilizer application and $112 \mathrm{~kg} / \mathrm{ha}$ of Dasanit ${ }^{5}$ (for nematode and soil insect control) were plowed and disced in during land preparation.

Lasso (Alachlor) was used as a preemergent herbicide at the rate of 4 $\mathrm{kg} / \mathrm{ha}$ of active ingredient. Rats were controlled by using Warfarin baits. Weekly spraying of Lannate $(1,2 \mathrm{~kg} / \mathrm{ha}$ ) was used to control insects. Dithane M-45 $(2 / 2 \mathrm{~kg} / \mathrm{ha})$ was applied when necessary for disease control.

Leaf samples were taken at silking stage to monitor possible $\mathrm{N}$ deficiency in the plants. The corn was harvested 100 to 120 days after planting. Ears were obtained from plants growing in $7.6 \mathrm{~m}$ of the two center rows of each plot and stover from $3.8 \mathrm{~m}$ of the same rows. Sub-samples were taken for determining shelling percentage and moisture and $\mathrm{N}$ content. Soil samples were taken before planting and analyzed for selected chemical properties (table 1). All data were statistically analyzed.

\section{RESULTS AND DISCUSSION}

Plant growth was excellent on the irrigated soils (Humatas and Bayamón), but was reduced on the other two soils (Catalina and Torres)

\footnotetext{
${ }^{5}$ Trade names are used in this publication solely for the purpose of providing specific information. Mention of a trade name does not constitute a guarantee of warranty of equipment or materials by the Agricultural Experiment Station of the University of Puerto Rico or an endorsement over other equipment or materials not mentioned.
} 
TABLE 1.-Selected chemical properties of soils used in $N$ experiments

\begin{tabular}{|c|c|c|c|c|c|c|c|c|c|c|}
\hline \multirow{2}{*}{ Soil } & \multirow{2}{*}{ Depth } & \multirow{2}{*}{$\mathrm{OM}$} & \multirow{2}{*}{$\mathrm{N}$} & \multirow{2}{*}{$\mathrm{pH}$} & \multicolumn{2}{|c|}{$\mathrm{CEC}$} & \multicolumn{4}{|c|}{ Exchangeable cations } \\
\hline & & & & & $\mathrm{NH}_{4} \mathrm{OAC}$ & ¿ Cations & $\mathrm{Ca}^{2+}$ & $\mathrm{Mg}^{2+}$ & $\mathrm{K}^{+}$ & $\mathrm{Al}^{3+}$ \\
\hline & $\mathrm{Cm}$ & $\%$ & $\%$ & & & & $e q / 100 \mathrm{~g}$ & & & \\
\hline \multirow{2}{*}{$\begin{array}{l}\text { Humatas (Typic Tropohumults; } \\
\text { clayey, mixed, isohyper- } \\
\text { thermic) }\end{array}$} & $0-25$ & 3.7 & 0.17 & 5.0 & 17.0 & 7.9 & 6.4 & 0.8 & 0.7 & 0.0 \\
\hline & $25-50$ & 1.2 & & 4.6 & 13.6 & 12.4 & 3.0 & .8 & .2 & 8.4 \\
\hline \multirow{2}{*}{$\begin{array}{l}\text { Torres (Orthoxic Tropudults; clayey, } \\
\text { mixed, isohyperthermic) }\end{array}$} & $0-25$ & 3.6 & .23 & 4.7 & 13.0 & 7.4 & 5.6 & 1.2 & .4 & .2 \\
\hline & $25-50$ & .9 & & 4.8 & 9.8 & 6.8 & 2.0 & .4 & .4 & 4.0 \\
\hline \multirow{2}{*}{$\begin{array}{l}\text { Catalina (Tropeptic Haplorthox; } \\
\text { clayey, kaolinitic, isohyper- } \\
\text { thermic) }\end{array}$} & $0-25$ & 3.9 & .24 & 5.5 & 15.0 & 8.7 & 7.1 & 1.0 & .6 & .0 \\
\hline & $25-50$ & 1.2 & & 5.3 & 8.2 & 4.8 & 4.0 & .6 & .0 & .2 \\
\hline \multirow{2}{*}{$\begin{array}{l}\text { Bayamón (Typic Haplorthox; psam- } \\
\text { mentic, oxidic, isohyper- } \\
\text { thermic) }\end{array}$} & $0-25$ & 1.6 & .07 & 4.9 & 3.7 & 2.5 & 1.3 & 0.8 & .1 & .3 \\
\hline & $25-50$ & .7 & & 4.8 & 2.9 & 2.3 & 1.2 & .7 & .0 & .4 \\
\hline
\end{tabular}


due to much less than average rainfall in May, June, and July. Cumulative rainfall at the four sites during the crop growth period was less than $22.8 \mathrm{~cm}$ (9 in).

High grain yields were obtained on Humatas ( 8.4 tons/ha, 134 bu/acre) (table 2), but the maximum yield on Bayamón was only 5.4 tons/ha. The lower final yields on Bayamón could be attributed to late planting and to a moderate southern leaf blight (Helminthosporium maydis) attack that was first noted at this site when the corn plants were in full silk. This is substantiated by the observation that the grain/stover ratios for the $N$ fertilized corn averaged 1.20 on Humatas and only 0.72 on Bayamón.

In a winter crop on Bayamón, Funk's was very seriously damaged by earworms. Thus, it appears that it has a higher grain yield potential than the tropical hybrid X-306 used in the previous N experiments. ${ }^{4}$ However,

TABLE 2.-Effect of $N$ fertilizer rate on corn yield and $N$ content, Bayamón soil, Manati, 1974

\begin{tabular}{|c|c|c|c|c|c|c|c|}
\hline $\begin{array}{l}\text { Treat- } \\
\text { ment }\end{array}$ & $N$ applied & $\begin{array}{l}\text { Grain yield } \\
\left(15 \% \mathrm{H}_{2} \mathrm{O}\right)\end{array}$ & $\begin{array}{l}\text { Stover } \\
\text { yield }\end{array}$ & $\begin{array}{l}\text { Dry } \\
\text { grain/ } \\
\text { stover }\end{array}$ & Grain N & Stover N & $\begin{array}{l}\text { Grain } \\
\text { plus } \\
\text { stover N }\end{array}$ \\
\hline & $\mathrm{Kg} / \mathrm{h} \mathrm{a}^{2}$ & Tons/ha' & Tons/ha & & $\mathrm{Kg} / \mathrm{ha}$ & $\mathrm{Kg} / \mathrm{ha}$ & Kg/ha \\
\hline 1 & 0 & $4.5 \mathrm{a}^{1}$ & $5.3 \mathrm{a}$ & 0.57 & $53 a$ & $32 \mathrm{a}$ & $85 \mathrm{a}$ \\
\hline 2 & 60 & $5.1 \mathrm{a}$ & $6.7 \mathrm{a}$ & .65 & $64 \mathrm{abc}$ & $53 \mathrm{ab}$ & $117 \mathrm{~b}$ \\
\hline 3 & 120 & $4.4 \mathrm{a}$ & $6.4 \mathrm{a}$ & .58 & $57 \mathrm{ab}$ & $51 \mathrm{ab}$ & $108 \mathrm{~b}$ \\
\hline 4 & 140 & $5.0 \mathrm{a}$ & $6.7 \mathrm{a}$ & .63 & $70 \mathrm{bc}$ & $59 \mathrm{~b}$ & $129 \mathrm{bc}$ \\
\hline 5 & 160 & $5.1 \mathrm{a}$ & $7.2 \mathrm{a}$ & .60 & $69 \mathrm{bc}$ & $58 \mathrm{~b}$ & $127 \mathrm{bc}$ \\
\hline 6 & 180 & $5.0 \mathrm{a}$ & $4.8 \mathrm{a}$ & .89 & $69 \mathrm{abc}$ & $46 \mathrm{ab}$ & $115 \mathrm{~b}$ \\
\hline 7 & 200 & $5.4 \mathrm{a}$ & $4.7 \mathrm{a}$ & .98 & $74 \mathrm{~cd}$ & $46 \mathrm{ab}$ & $120 \mathrm{~b}$ \\
\hline
\end{tabular}

${ }^{1}$ Values in a column followed by the same letter are not significantly different at the $5 \%$ level using Duncan's multiple range test.

${ }^{2} \mathrm{Kg} / \mathrm{ha}=0.89 \mathrm{lb} / \mathrm{acre} ;$ tons $/ \mathrm{ha}=890 \mathrm{lb} / \mathrm{acre}$.

it seemed susceptible to earworms and disease. Talleyrand and LugoLópez ${ }^{5}$ reported the same tendency in Funk's G-795W and Pioneer X-306-B, an improved selection of the Pioneer X-306. Unless these pests either are not present or are controlled by massive sprayings, grain yield would probably be considerably less on the average for Funk's G-795W than for Pioneer X-306 or X-306-B.

Because of the higher grain/stover ratios of Funk's than of Pioneer $\mathrm{X}-306$ in previous years at both sites, ${ }^{4}$ the grain yield per unit of $\mathrm{N}$ with Funk's was higher than expected. This, coupled with the slightly lower total yields than anticipated and the unexpectedly high $\mathrm{N}$ supplying power in the Bayamón soil, resulted in most of the $\mathrm{N}$ fertilizer rates being higher than optimum at the two irrigated sites (tables 2 and 3). In the Bayamón soil, $60 \mathrm{~kg} / \mathrm{ha}$ of fertilizer $\mathrm{N}$ were sufficient to produce a near maximum grain yield of 5.1 tons/ha. The optimum rate for the 
Humatas soil at Corozal appeared to be between 60 and $120 \mathrm{~kg} / \mathrm{ha}$ of $\mathrm{N}$. The apparent $\mathrm{N}$ fertilizer recoveries in Humatas were 60 to $72 \%$ for the lower, near-optimum rates of fertilizer $\mathrm{N}$. This confirms the previous observation that when there is response to $\mathrm{N}$ fertilizer, the recovery of postplant applied $\mathrm{N}$ is comparable on the average to that observed in temperate areas. ${ }^{6}$ The $\mathrm{N}$ supplying power of the Bayamón soil had risen

TABLE 3.-Effect of $N$ fertilizer rate on corn yield and $N$ content, Humatas soil, Corozal, 1974

\begin{tabular}{|c|c|c|c|c|c|c|c|c|}
\hline $\begin{array}{c}\text { Treat- } \\
\text { ment } \\
\text { no. }\end{array}$ & $\begin{array}{c}\mathrm{N} \\
\text { applied }\end{array}$ & $\begin{array}{l}\text { Grain yield } \\
\left(15 \% \mathrm{H}_{2} \mathrm{O}\right)\end{array}$ & $\begin{array}{l}\text { Stover } \\
\text { yield }\end{array}$ & $\begin{array}{l}\text { Dry } \\
\text { grain/ } \\
\text { stover }\end{array}$ & $\stackrel{\text { Grain }}{N}$ & $\begin{array}{l}\text { Stover } \\
\mathrm{N}\end{array}$ & $\begin{array}{c}\text { Grain } \\
\text { plus } \\
\text { stover } \mathrm{N}\end{array}$ & $\begin{array}{l}\text { Apparent }{ }^{2} \\
\text { fertilizer } \\
\text { N recovery }\end{array}$ \\
\hline & Kg/ha & Tons/ha & Tons/ha & & $\mathrm{Kg} / \mathrm{ha}$ & Kg/ha & Kg/ha & $\%$ \\
\hline 1 & 0 & $3.3 \mathrm{a}^{1}$ & $4.2 \mathrm{a}$ & 0.67 & 31 a & $16 \mathrm{a}$ & $47 \mathrm{a}$ & - \\
\hline 2 & 60 & $6.3 \mathrm{~b}$ & $5.1 \mathrm{ab}$ & 1.05 & $66 \mathrm{~b}$ & $24 \mathrm{ab}$ & $90 \mathrm{~b}$ & 72 \\
\hline 3 & 120 & $7.6 \mathrm{bc}$ & $5.8 \mathrm{~b}$ & 1.11 & $89 \mathrm{c}$ & $30 \mathrm{~b}$ & $119 c$ & 60 \\
\hline 4 & 140 & $7.4 \mathrm{bc}$ & $5.2 \mathrm{~b}$ & 1.21 & $93 \mathrm{c}$ & 35 bc & $128 \mathrm{c}$ & 58 \\
\hline 5 & 160 & $7.6 \mathrm{bc}$ & $5.7 \mathrm{~b}$ & 1.13 & $96 \mathrm{c}$ & $41 \mathrm{~cd}$ & $137 \mathrm{c}$ & 56 \\
\hline 6 & 180 & $7.0 \mathrm{bc}$ & $5.1 \mathrm{ab}$ & 1.17 & $97 \mathrm{c}$ & $35 \mathrm{bc}$ & $132 \mathrm{c}$ & 47 \\
\hline 7 & 200 & $8.4 \mathrm{c}$ & $5.6 \mathrm{ab}$ & 1.28 & $102 \mathrm{c}$ & $35 \mathrm{bc}$ & $137 \mathrm{c}$ & 45 \\
\hline
\end{tabular}

'Values in a column followed by the same letter are not significantly different at the $5 \%$ level using Duncan's multiple range test.

${ }^{2}$ Fertilized plant $\mathrm{N}$ minus check plant $\mathrm{N} /$ fertilizer $\mathrm{N}$ applied.

TABLE 4.-Effect of $N$ fertilizer rate on corn yield and $N$ content, Catalina soil, Barranquitas, summer 1974

\begin{tabular}{|c|c|c|c|c|c|c|c|}
\hline $\begin{array}{c}\text { Treatment } \\
\text { no. }\end{array}$ & $\begin{array}{c}\mathrm{N} \\
\text { applied }\end{array}$ & $\begin{array}{c}\text { Grain } \\
\text { yield } \\
\left(15 \% \mathrm{H}_{2} \mathrm{O}\right)\end{array}$ & $\begin{array}{l}\text { Stover } \\
\text { yield }\end{array}$ & $\begin{array}{l}\text { Dry } \\
\text { grain/ } \\
\text { stover }\end{array}$ & $\begin{array}{l}\text { Grain } \\
\mathrm{N}\end{array}$ & $\begin{array}{c}\text { Stover } \\
N\end{array}$ & $\stackrel{\text { Total }}{\mathrm{N}}$ \\
\hline & $\mathrm{Kg} / \mathrm{ha}$ & Tons/ha & Tons/ha & & $\mathrm{Kg} / \mathrm{ha}$ & $\mathrm{Kg} / \mathrm{ha}$ & $\mathrm{Kg} / \mathrm{ho}$ \\
\hline 1 & 0 & 3.6 & 2.6 & 1.18 & 53 & 26 & 79 \\
\hline 2 & 40 & 3.8 & 2.3 & 1.40 & 53 & 28 & 81 \\
\hline 3 & 80 & 4.1 & 2.7 & 1.29 & 61 & 30 & 91 \\
\hline 4 & 100 & 3.8 & 2.2 & 1.47 & 56 & 30 & 86 \\
\hline 5 & 120 & 3.5 & 2.1 & 1.42 & 51 & 25 & 76 \\
\hline 6 & 140 & 3.8 & 1.8 & 1.79 & 57 & 23 & 80 \\
\hline 7 & 160 & 4.0 & 2.5 & 1.36 & 57 & 30 & 87 \\
\hline Average & & 3.8 & 2.3 & 1.40 & 56 & 27 & 83 \\
\hline
\end{tabular}

sharply over that observed in previous corn crops. The total $\mathrm{N}$ content of the plants in the check plots was $85 \mathrm{~kg} / \mathrm{ha}$ (table 2 ), compared to $51 \mathrm{~kg} / \mathrm{ha}$ in the irrigated corn crop in $1972 .{ }^{4}$

There were no yield or $\mathrm{N}$ uptake responses to $\mathrm{N}$ applied to the Catalina

${ }^{6}$ Talleyrand, H., and Lugo-López, M. A., Performance of high-yielding corn hybrids Pioneer X-306-B and Funk's G-795W at high levels of fertilization in the acid and relatively infertile soils (Ultisols and Oxisols) of Puerto Rico, J. Agr. Univ. P.R. 60 (1): 132-4. 1976. 
or Torres soils in the summer of 1974 (tables 4 and 5). The severe drought during the first 2 months after planting both experiments was the probable cause for this lack of $\mathrm{N}$ response. Late planting coupled with the severe drought probably contributed in large measure to the reduced stover yields, which were less than half of those obtained in the irrigated Humatas and Bayamón soils. Although grain/stover ratios were high at both sites, plants were very small and grain yields were considerably below that obtained on the Humatas soil. The $\mathrm{N}$ supplying power of the soil was sufficient to provide the 70 to $90 \mathrm{~kg} / \mathrm{ha}$ of plant $\mathrm{N}$ for maximum yields at both sites, and thus there was no response to fertilizer $\mathrm{N}$. These results confirm the observations by Fox et al. ${ }^{4}$ that supplemental irrigation is apparently necessary for consistent high yield of crops like corn in north central Puerto Rico even in the rainy season. In this

Table 5.-Effect of $N$ fertilizer rate on corn yield and $N$ content, Torres soil, Cidra, summer 1974

\begin{tabular}{|c|c|c|c|c|c|c|c|}
\hline $\begin{array}{c}\text { Treatment } \\
\text { no. }\end{array}$ & $\stackrel{N}{\text { applied }}$ & $\begin{array}{c}\text { Grain } \\
\text { yield } \\
\left(15 \% \mathrm{H}_{2} \mathrm{O}\right)\end{array}$ & $\begin{array}{l}\text { Stover } \\
\text { yield }\end{array}$ & $\begin{array}{l}\text { Dry } \\
\text { grain/ } \\
\text { stover }\end{array}$ & $\stackrel{\text { Grain }}{N}$ & $\begin{array}{l}\text { Stover } \\
\mathrm{N}\end{array}$ & $\begin{array}{c}\text { Total } \\
\mathrm{N}\end{array}$ \\
\hline & $\mathrm{Kg} / \mathrm{ha}$ & Tons/ha & Tons/ha & 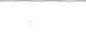 & $\mathrm{Kg} / \mathrm{h} \alpha$ & Kg/ha & Kg/ha \\
\hline 1 & 0 & 4.4 & 1.8 & 2.08 & 59 & 15 & 74 \\
\hline 2 & 20 & 4.1 & 2.2 & 1.58 & 56 & 20 & 76 \\
\hline 3 & 40 & 4.8 & 2.0 & 2.04 & 64 & 16 & 80 \\
\hline 4 & 50 & 3.7 & 2.4 & 1.31 & 54 & 20 & 74 \\
\hline 5 & 60 & 4.2 & 2.1 & 1.70 & 62 & 18 & 80 \\
\hline 6 & 80 & 4.0 & 1.7 & 2.00 & 56 & 16 & 72 \\
\hline 7 & 100 & 4.2 & 1.3 & 2.75 & 59 & 13 & 72 \\
\hline Average & & 4.2 & 1.9 & 1.88 & 58 & 17 & 75 \\
\hline
\end{tabular}

connection recent research ${ }^{7}$ in the Oxisols of Campo Cerrado near Brasilia (Brazil) shows that improved water control in the humid tropics is essential for more efficient utilization of fertilizer. The frequent occurrence of dry periods during the rainy season may cause substantial crop yield reduction if supplemental irrigation is not used. The work. conducted at Campo Cerrado indicates that on the average only about half the potential yield of a crop such as corn may be expected in this area without supplementary water.

Apparently high corn yields are possible in Puerto Rico, but insect and disease resistance must be bred into the hybrids, and adequate water must be supplied to insure these yields.

${ }^{7}$ Drosdoff, M., Soil fertility in the humid tropics, Progr. Rep. 1973-1974, submitted to USAID, Cornell Univ., Ithaca, N.Y., 1974. 


\section{RESUMEN}

Se realization experimentos de campo utilizando el maß́z híbrido Funk's G795W en cuatro suelos representativos de los Oxisols y Ultisols de las regiones tropicales húmedas: en dos Oxisols (Manatí y Barranquitas) y en dos Ultisols (Corozal y Cidra). Los tratamientos incluían niveles variables de $\mathrm{N}$ que fluctuaban de 0 a $200 \mathrm{Kg}$./Ha. Los objetivos principales eran determinar el rendimiento potencial y el nivel optimo de $\mathrm{N}$ que se requiere para la producción del maíz Funk's G-795W, un híbrido de grano blanco de alto potencial productivo.

Los resultados indican que: 1) se obtuvieron altos rendimientos de $8.4 \mathrm{~T}$./Ha. en Corozal, pero los rendimientos máximos en Manatí sólo alcanzaron a $5.4 \mathrm{~T}$./Ha.; 2) en el suelo Bayamón (Manatí), $60 \mathrm{Kg}$./Ha. de $\mathrm{N}$ fueron suficientes para lograr un rendimiento casi máximo de grano; en el suelo Humatas (Corozal), el nivel óptimo de $\mathrm{N}$ fluctúa entre 60 y $120 \mathrm{Kg}$. Ha.; 3) la razón de grano a rastrojo en el caso del maíz abonado con $\mathrm{N}$ alcanzó, en promedio, 1.20 en Corozal y sólo 0.72 en Manatí; 4) la capacidad de suministro de $\mathrm{N}$ en el suelo Bayamón, un Oxisol arenoso, ha aumentado marcadamente sobre el obtenido en años anteriores; 5) no hubo respuesta estadísticamente significativa en redimientos y en la absorción de $\mathrm{N}$ que se pueda atribuí al $\mathrm{N}$ aplicado, ni en el caso del suelo Catalina (Barranquitas), ni tampoco en el del suelo Torres (Cidra); en ambos sitios se sembró tardíamente y no había instalaciones para regar. A la tardanza de la siembra y la sequía prolongada puede probablemente atribuirse la reducción en el rendimiento de rastrojo a menos de la mitad de los obtenidos en los dos sitios en que se pudo regar (Corozal y Manatí). Los rendimientos de grano no alcanzaron las $8.4 \mathrm{~T}$./Ha. obtenidas en Corozal. La capacidad del suelo para suministrar $\mathrm{N}$ fue suficiente para proveer los $70-90 \mathrm{Kg}$. $/ \mathrm{Ha}$. de $\mathrm{N}$ en la planta necesarios para rendimientos máximos en ambas localidades, pero no hubo respuesta a las aplicaciones de abonos con $\mathrm{N}$; 6) en Corozal, las recuperaciones aparentes de $\mathrm{N}$ proveniente del abono fueron de $60-72 \%$, en el caso de las aplicaciones de $\mathrm{N}$ en dosis más bajas. 